\title{
Environmental-friendly architectural water-borne paint for outdoor application: twenty years of experience in Belarus and Lithuania
}

\author{
Krystsina Khaletskaya ${ }^{\text {a }}$, Vitali Khaletski ${ }^{\text {b }}$, Sigita Švedienéc, Aušra Mažeikienè ${ }^{\text {d }}$ \\ ${ }^{a, b}$ Brest State Technical University, Moskovskaya str. 267, Brest 224017, Belarus \\ ${ }^{c}$ Vilniaus kolegija/University of Applied Sciences, Buivydiškiu str. 1, Buivydiškes, LT-14160 Vilnius area, Lithuania \\ ${ }^{d}$ Department of Water Management, Vilnius Gediminas Technical University, \\ Sauletekio ave. 11, LT-10223 Vilnius, Lithuania
}

\begin{abstract}
Water-borne paints first appeared on the market of building materials in Belarus and Lithuania in the early 1990s. These paints had to compete with solvent-based products traditionally used for mineral surfaces. Water-borne paints were able to quickly gain popularity despite the initial doubts of consumers and higher price. This was due to a number of advantages of water-borne paints such as high weather resistance, light fastness, low water absorption, resistance to chalking, high adhesion. Typical formulations of water-borne paints developed and implemented in the production by the authors were analyzed in the article. Pure acrylic and styrene-acrylic polymer dispersions were used as film formers, talcum and marble powder were used as fillers. Monitoring of different types of painted surfaces conducted by the authors showed not only the advantages but some disadvantages of the paints. These include delamination of coatings due to their incompatibility with the base, discoloration due to the use of organic pigments with low stability etc.

Directive 2004/42/CE of the European Parliament and of the council of 21 April 2004 on the limitation of emissions of volatile organic compounds (VOC) due to the use of organic solvents in certain paints and varnishes and vehicle refinishing products (in Lithuania) and Technical Regulations of the Customs Union "On the security of paints and varnishes" (in Belarus) show that water-borne paints with low VOC will tend to dominate in market.
\end{abstract}

Keywords: water-borne paints; acrylic; fascades; construction materials.

\begin{tabular}{|ll|}
\hline Nomenclature \\
PVC & pigment volume concentration \\
DIY & do-it-yourself \\
VOC & volatile organic compounds \\
MPC & maximum permissible concentrations \\
MF & mass fraction \\
\hline
\end{tabular}

\section{Introduction}

Water-borne paints and varnishes for painting of facades first appeared on the market of construction materials of Belarus and the Republic of Lithuania in the early 1990s. Initially the consumers cautiously met new products. This was due to two main reasons. First, water-based paints were used for internal works in our countries even since the 1970s. As the film former PVA dispersion was used in such systems. Paints themselves were of low waterproofness and quickly got yellow. Therefore, water systems in the minds of the mass consumer firmly associated with poor quality. Secondly, water-borne facade paints were originally relatively expensive exceeding the price of paints based on organic solvents. But over time, the inertia of the mindset of mass consumer has been overcome, and water-borne paints started their broad expansion on the market of building materials, which has fallen to the 2000s. This resulted in appearance of large number of local producers since the production of water paints of segment DIY (do-it-yourself) does not require considerable investments, expensive equipment and significant labour resources. The main requirements include availability of qualitative raw material, which could be imported to Belarus and Lithuania. 
Water-borne paints allowed the consumers to receive qualitative coating of facades distinguished by long time service (10 years or more), high light resistance, weather ability, good adhesion to the basis and absence of chalking. Henceforth the facades did not have to be renewed each season. Furthermore, the use of computer tinting provided the architects with the opportunity to work with colour catalogues with lots of colour shades.

But there was another reason, which helped the promotion of water-based paints to a great extent. Absence of volatile organic solvents, low content of residual monomer in the film former, the absence of secondary toxic components in the formulas, avoidance of the use of heavy metal compounds as pigments allows us to consider the water-borne paints to be environmentally-friendly materials. This feature of paints has been used as marketing ploy by almost all manufacturing companies during the positioning of goods to the mass consumer. Moreover, at the beginning of the 2000s, after it had been determined that many volatile organic compounds (VOCs) used as solvents (white spirit, xylene, toluene) were greenhouse gases, their use was restricted by legislation [1-7]. Directive 2004/42/CE of the European Parliament and of the council of 21 April 2004 on the limitation of emissions of volatile organic compounds (VOC) were adopted in the countries of European Union [8]. In Belarus, there are restrictions in the form of Technical Regulations of the Customs Union "On the security of paints and varnishes".

The requirements of national legislation according to the content of most common organic solvents in various objects are given in Table 1.

Table 1. Environmental, toxicological and hygienic characteristics of some organic solvents as required by laws of the Republic of Belarus and the Republic of Lithuania

\begin{tabular}{|c|c|c|c|c|c|}
\hline \multirow{2}{*}{\multicolumn{2}{|c|}{ Index }} & \multicolumn{3}{|c|}{ Solvent } & \multirow{2}{*}{ Literature } \\
\hline & & White spirit & Toluene & \multirow[t]{2}{*}{ Xylol } & \\
\hline \multicolumn{5}{|c|}{ The Republic of Belarus } & \\
\hline Hazard class & & 4 & 3 & 3 & 1 \\
\hline \multirow[t]{3}{*}{$\begin{array}{l}\text { Maximum permissible concentrations } \\
(\mathrm{MPC}) \text { in air of residential areas, } \mathrm{mg} / \mathrm{m}^{3}\end{array}$} & Max. & 1.0 & 0.6 & 0.2 & 1 \\
\hline & Day average & 0.4 & 0.3 & 0.1 & 1 \\
\hline & Annual average. & 0.2 & 0.1 & 0.02 & 1 \\
\hline \multicolumn{2}{|c|}{ Maximum permissible level of leather contamination, $\mathrm{mg} / \mathrm{cm}^{2}$} & - & 0.05 & 1.75 & 2 \\
\hline \multicolumn{2}{|c|}{$\begin{array}{l}\text { MPC in water bodies of economic - drinking and cultural - } \\
\text { domestic water use, } \mathrm{mg} / \mathrm{l}\end{array}$} & - & 0.5 & 0.05 & 3 \\
\hline \multicolumn{2}{|l|}{ MPC in drinking water, $\mathrm{mg} / \mathrm{l}$} & - & 0.5 & 0.05 & 4 \\
\hline \multicolumn{2}{|l|}{ MPC in the soil, $\mathrm{mg} / \mathrm{kg}$ of soil } & - & 0.3 & 0.3 & 5 \\
\hline \multicolumn{6}{|c|}{ The Republic of Lithuania } \\
\hline \multicolumn{2}{|l|}{ MPC in air of residential areas, $\mathrm{mg} / \mathrm{m}^{3}$} & 1.0 & 0.6 & 0.2 & 6 \\
\hline \multicolumn{2}{|c|}{$\begin{array}{l}\text { MPC in water bodies that are not designed for household } \\
\text { water, } \mathrm{mg} / \mathrm{l}\end{array}$} & - & 1.0 & 1.0 & 7 \\
\hline \multicolumn{2}{|c|}{ MPC in water bodies of household water, $\mathrm{mg} / \mathrm{l}$} & - & 0.7 & 0.5 & 7 \\
\hline \multicolumn{2}{|c|}{$\begin{array}{l}\text { MPC at the points of water sampling for supply of drinking } \\
\text { water, } \mathrm{mg} / \mathrm{l}\end{array}$} & - & 0.17 & 0.3 & 7 \\
\hline
\end{tabular}

Water paints are offered by modern chemical industry a wide range of film formers of different chemical nature. Despite this, most paints used on the markets of Belarus and Lithuania contain styrene-acrylic copolymer dispersion as their basis. The main reason for this is relatively low cost of such a polymer. Part of pure acrylic polymers is much smaller. Also, there is a small amount of colours additionally containing silicone resins as a modifier.

\section{Method of experiment}

The authors have developed and tested the formulas of water-borne paints for facades in an industrial environment both on the basis of styrene-acrylic dispersion and pure acrylic film former. Exemplary formulas are given in Table 2.

The manufacturing of test paint batches was performed using a laboratory dissolver with fixed speed of cutter rotation of $900 \mathrm{rpm}$ in polymeric containers into a single phase. During the determination of content of components, convenience of formula transfer for the industrial manufacture was considered. Estimated pigment volume concentration (PVC) for the composition of No 1 was $65.28 \%$, for composition No $2-72.28 \%$. Calculated mass fraction (MF) for the composition No 1 was $63.83 \%$, for the composition No $2-61.20 \%$.

Titanium dioxide as a white pigment obtained by means of the chloride method (Ti-Pure R $706^{\mathrm{TM}}$, Du Pont) was used in the formula. The surface of pigment particles was treated with oxides of silicon and aluminium, whereby it is resistant to photo-degradation but also has high whiteness. The median size of pigment particles is 0.36 microns.

Silicone emulsion was additionally introduced in the composition No1 in order to reduce water absorption and increase the vapour permeability of the coating. The mechanism of film formers modification is based on their thermodynamic incompatibility with silicone oligomers. After introducing the silicone in polymer matrix, a two-phase system is formed there, and the film becomes non uniform (Figure 1). The layer of varnish-paint coating becomes repellent; a system of micro-pores sufficient in their size for the migration of water vapour and carbon dioxide and too small for the seepage of 
liquid water is formed there. Herewith traditional stickiness inherent to most pure acrylic and styrene acrylic copolymers also decreases $[9,10]$.

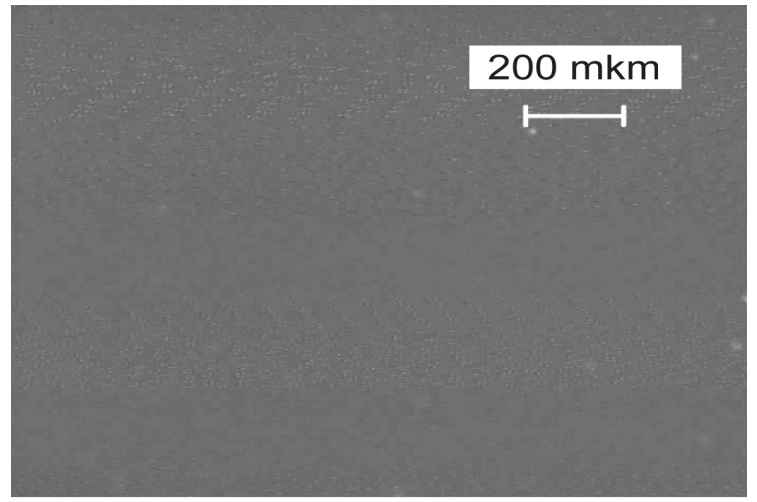

(a)

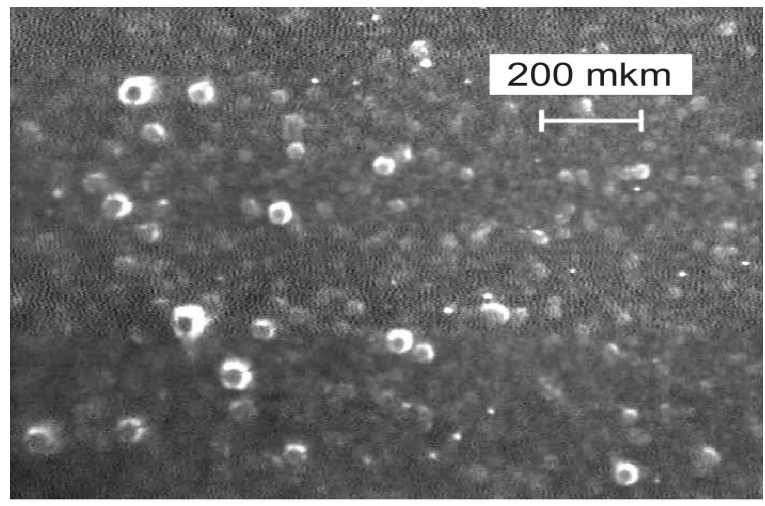

(b)

Fig. 1. Photography of films obtaining from sterol-acrylic dispersion: (a) primary dispersion, (b) dispersion with $30 \%$ silicone emulsion. Thickness of films 100 microns, microscope type - "Планар-ТМ"

Compositions of paints after testing of their properties and approval of the formula were reproduced under industrial environments. Mass of one batch was approximately $3000 \mathrm{~kg}$.

Table 2. Estimated formula of facade paints for mineral surfaces

\begin{tabular}{|c|c|c|c|}
\hline \multirow{2}{*}{ No } & \multirow{2}{*}{ Component Name } & \multicolumn{2}{|l|}{ Content, mass \% } \\
\hline & & Composition 1 & Composition 2 \\
\hline 1. & Water & 24.86 & 30.95 \\
\hline 2. & Calcite (marble powder), 2 micron fraction & 13.93 & 25.45 \\
\hline 3. & Calcite (marble powder), 5 micron fraction & 19.15 & 15.27 \\
\hline 4. & Talc & 5.22 & 3.39 \\
\hline 5. & Aluminium silicate & 0.35 & 0.34 \\
\hline 6. & White pigment (titanium dioxide) & 12.18 & 7.63 \\
\hline \multirow[t]{2}{*}{7.} & $\begin{array}{l}\text { Polymeric film former } \\
\text { (aqueous dispersion of copolymer of polyacrylates and styrene) }\end{array}$ & 19.15 & - \\
\hline & (aqueous dispersion of pure acrylic polymer) & - & 14.59 \\
\hline 8. & Hydroxymethyl cellulose (rheological additive) & 0.21 & 0.34 \\
\hline 9. & Polyacrylic thickener (rheological additive) & 0.24 & 0.20 \\
\hline 10. & Coalescent (Dalpad Filmer ${ }^{\mathrm{TM}}$, Dow Chemical Europe) & 0.87 & 0.51 \\
\hline 11. & $40 \%$ aqueous solution of sodium polyacrylate (dispersing agent) & 0.53 & 0.49 \\
\hline 12. & Defoamer based on mineral oil & 0.31 & 0.31 \\
\hline 13. & In-can preservative & 0.35 & 0.31 \\
\hline 14. & Film preservative & 0.24 & - \\
\hline 15. & Sodium polyphosphate (water softener) & 0.21 & 0.20 \\
\hline 16. & Ammonia (acidity regulator) & 0.02 & 0.02 \\
\hline 17. & Silicone emulsion - modifier & 2.20 & - \\
\hline
\end{tabular}

The authors have conducted a study of derived facade paint, and at that, the paint itself and the coating on its basis have been studied as well. Testing procedures complied with the technical normative legal acts in force in the varnish industry. Viscosity according to Brookfield was determined at $20 \mathrm{rpm}$ at $20^{\circ} \mathrm{C}$ using spindle No 05 on a rotational viscometer, model RVDV-E, made by Brookfield Engineering Inc. Viscosity by ICI was determined at $750 \mathrm{rpm}$ at $23{ }^{\circ} \mathrm{C}$ on viscometer type "cone - plate", model CPD 2000 D1LT, made by Research Equipment London. Colour coordinates of the coating and optical coverage determined on a spectrophotometer X-Rite SP 62. Standard chessboards Leneta Charts 10B were used as substrate for the determination of optical characteristics. 


\section{Results and discussion}

The results of the study are presented in Table 3 .

Table 3. Characteristics of developed facade paints designed for mineral surfaces

\begin{tabular}{|c|c|c|c|c|}
\hline \multirow{2}{*}{ No } & \multirow{2}{*}{ Indicator } & \multirow{2}{*}{ Test method } & \multicolumn{2}{|c|}{ Actual value } \\
\hline & & & Composition 1 & Composition 2 \\
\hline 1. & Appearance of the coating & ГОСТ 28196 & \multicolumn{2}{|c|}{ Smooth and uniform matted surface } \\
\hline 2. & Mass fraction of non-volatile substances, $\%$ & ГОСТ 17537 & 62.1 & 61.8 \\
\hline 3. & $\mathrm{pH}$-value & ГОСТ 28196 & 8.4 & 8.2 \\
\hline 4. & Spreading rate of dried film, $\mathrm{g} / \mathrm{m}^{2}$ & ГОСТ 8784 & 120 & 120 \\
\hline 5. & Grinding, $\mu \mathrm{m}$ & ГОСТ 6589 & 30 & 30 \\
\hline 6. & $\begin{array}{l}\text { Resistance of the coating to static effect of water at a temperature of } \\
(20 \pm 2)^{\circ} \mathrm{C}, \mathrm{h}\end{array}$ & ГОСТ 9.403 & $\begin{array}{l}\text { At least } \\
96\end{array}$ & $\begin{array}{l}\text { At least } \\
60\end{array}$ \\
\hline 7. & Drying time to degree 3 at temperature of $(20 \pm 2)^{\circ} \mathrm{C}, \mathrm{h}$ & ГОСТ 19007 & $\begin{array}{c}\text { At least } \\
1\end{array}$ & $\begin{array}{c}\text { At least } \\
1\end{array}$ \\
\hline 8. & Coefficient of vapour permeability, $\mathrm{mg} / \mathrm{m} \cdot \mathrm{h} \cdot \mathrm{Pa}$ & ГОСТ 28575 & 0.022 & 0.011 \\
\hline 9. & Viscosity of the paint acc. to Brookfield, $20 \mathrm{rpm}$, cps & & 8500 & 8820 \\
\hline 10. & Viscosity of the paint acc. to ICI, $750 \mathrm{rpm}, \mathrm{cps}$ & & 115 & 120 \\
\hline 11. & Optical spreading rate (opacity), \% & & 95.65 & 96.40 \\
\hline 12. & Colour in Lab coordinates & & $\begin{array}{l}\mathrm{L} 96.11 \\
\mathrm{a}-0.44 \\
\mathrm{~b}+1.53\end{array}$ & $\begin{array}{l}\mathrm{L} 96.46 \\
\mathrm{a}-0.55 \\
\mathrm{~b}+1.51\end{array}$ \\
\hline
\end{tabular}

Developed varnish materials were applied for facade painting on construction sites in the Republic of Belarus, the Baltic States and the Russian Federation. Annual monitoring of the condition of coatings showed that, subject to compliance with the technology of paint application, the coatings are able to maintain their performance for a long time (10 years). Nevertheless, we can distinguish the following main problems associated with the use of water-borne paints and varnishes:

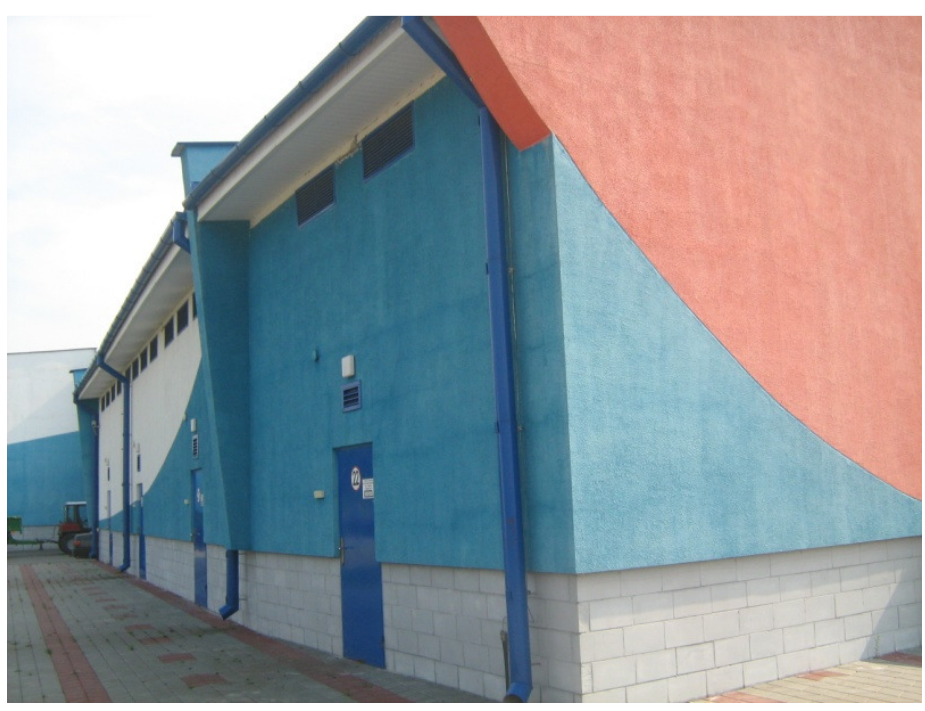

Fig. 2. Discoloration of coating due to the low light fastness of organic pigments

- A significant change in the colour of coating during the operation process (Figure 2). The reason for this phenomenon is the use of organic pigments for the tinting of facade paints with a low light fastness. Experience shows that inorganic pigments based on iron and chromium oxides, cobalt aluminates and bismuth vanadate are the most appropriate for the use in facade paint. Despite the relative rarity of the use in aqueous systems, Prussian blue is highly resistant to discolouration. However, many manufacturers use organic pigments for tinting of water-borne paints, most often phthalocyanine allowing the reception of saturated blue and green colours and of much lower cost than compounds of cobalt and chromium of similar colour. Such unjustified economy leads to discolouration of coating which, in some cases, becomes visually noticeable in only a month after the paint application. Red, yellow, orange and purple organic pigments discolour even stronger.

- Flaking of coating from the base. There may be several reasons for this phenomenon. First, it is incompatibility of the coating with previous coating layers. Quite often such a situation is observed during restoration works when a new coating layer is applied on an old paint layer of different chemical nature. Secondly, flaking often occurs during noncompliance with the temperature regimes of paint application (painting at temperatures below $+8{ }^{\circ} \mathrm{C}$ and above $+30{ }^{\circ} \mathrm{C}$, painting during fog or drizzle, etc.). Flaking can also occur when a base was not properly primed. 
- Affection by microorganisms. Fragments of facade with excessive moisture are exposed to affection most often: such as bases of buildings or mouldings. In order to prevent this, film preservative is introduced in the paint composition, capable of suppressing the growth of microorganisms.

Insert of silicone modifier to the composition of paints let considerably enhance the penetration of vapour in wafer materials. However absorption of water remains fairly low. The optimal amount of silicone modifier must to be $>10 \%$ of total film former in the system. Further enlargement of modifier amount in the recipe of paint is not advisable economically. Such carpets (recipe 1) were approved like final layers in the warm-up systems of facade. Those secured correct gas circulation in the basement. The results of monitoring of objects indicate that the most critical period for the coatings is late autumn and early spring, when there is a daily transition of temperatures through $0{ }^{\circ} \mathrm{C}$, and hence, there is freezing / thawing of the moisture contained in the mineral base. Under these conditions, there is frequent formation of micro-cracks in plastic layer, which is accompanied by cracking up to the coating.

\section{Conclusions}

Water-borne materials based on acrylic film formers allow obtaining qualitative coatings for facades in moderate climate of Belarus and Lithuania. If the technology of the application of material is observed and inorganic pigments for tinting are chosen, the coatings that can be used for 10 years or more may be obtained. Insert of silicone modifier to the composition of paints let considerably enhance the penetration of vapour in wafer materials. The optimal amount of silicone modifier must to be $>10 \%$ of total film former in the system. Further enlargement of modifier amount in the recipe of paint is not advisable economically. Water-borne materials based on acrylic film were approved like final layers in the warm-up systems of facade. Thus the coating will maintain full range of operating characteristics.

\section{References}

[1] Предельно допустимые концентрации (ПДК) и ориентировочные безопасные уровни воздействия (ОБУВ) загрязняющих веществ в атмосферном воздухе населённых мест. [The maximum permissible concentration (MPC) and the occupational exposure limits (WEL) of pollutants in ambient air of residential areas]. ГН 2.1.6.12-46-2005 - Введ. 01.05.2006 - Минск: ГУ «Республиканский центр гигиены, эпидемиологии и общественного здоровья» Министерство здравоохранения Республики Беларусь [Minsk: SI “The Republican Center of Hygiene, Epidemiology and Public Health," The Ministry of Health of the Republic of Belarus], 2006. 190 c.

[2] Перечень регламентированных в воздухе рабочей зоны вредных веществ. Санитарные нормы, правила и гигиенические нормативы - Введ. [List of regulated for airborne pollutants. Sanitary norms, rules and hygienic standards - enter] 01.07.2009 - Минск: ГУ «Республиканский центр гигиены, эпидемиологии и общественного здоровья» Министерство здравоохранения Республики Беларусь [Minsk: SI "The Republican Center of Hygiene, Epidemiology and Public Health," The Ministry of Health of the Republic of Belarus], 2009. $146 \mathrm{c}$.

[3] Предельно допустимые концентрации (ПДК) химических веществ в воде водных объектов хозяйственно-питьевого и культурно-бытового водопользования [Mахimum allowable concentration (MAC) of chemical substances in water bodies of potable and cultural and community uses]. ГН 2.1.5.10-21-2003 - Введ. 01.04.2005 - Минск: ГУ «Республиканский центр гигиены, эпидемиологии и общественного здоровья» Министерство здравоохранения Республики Беларусь [Minsk: SI "The Republican Center of Hygiene, Epidemiology and Public Health," The Ministry of Health of the Republic of Belarus], 2004. $59 \mathrm{c}$.

[4] Питьевая вода. Гигиенические требования к качеству воды централизованных систем питьевого водоснабжения. Контроль качества [Drinking water Hygienic requirements for water quality of centralized drinking water supply. Quality control]. СанПиН 10-124 РБ 99. - Введ. 01.01.2000 - Минск: ГУ «Республиканский центр гигиены, эпидемиологии и общественного здоровья» Министерство здравоохранения Республики Беларусь [Minsk: SI "The Republican Center of Hygiene, Epidemiology and Public Health," The Ministry of Health of the Republic of Belarus], 2002. $108 \mathrm{c}$.

[5] Предельно допустимые концентрации (ПДК) и ориентировочно допустимые концентрации (ОДК) химических веществ в почве [Тhе maximum permissible concentration (MPC) and approximately permissible concentrations (UEC) of chemicals in soil]. ГН 2.1.7.12-1-2004 - Введ. 06.10.2004 - Минск: ГУ «Республиканский центр гигиены, эпидемиологии и общественного здоровья» Министерство здравоохранения Республики Беларусь [Minsk: SI "The Republican Center of Hygiene, Epidemiology and Public Health," The Ministry of Health of the Republic of Belarus], 2006. $-26 \mathrm{c}$.

[6] Teršalŭ, kurių kiekis aplinkos ore ribojamas pagal nacionalinius kriterijus, sąrašas ir ribinės aplinkos oro užterštumo vertes [Pollutants in the air in quantities is limited by national criteria and a list of limit values for environmental air pollution]. - 2007-06-11 Lietuvos Respublikos aplinkos ministro ir Lietuvos Respublikos sveikatos apsaugos ministro: isakymas Nr. D1-329/V-469. Vilnius: Aplinkos ir sveikatos apsaugos ministerijos [Lithuanian Minister of Environment of the Republic of Lithuania and the Minister of Health: Order No. D1-329/V-469th Vilnius: The Environment and the Ministry of Health], 2007. 12 p. Valstybès žinios. 2007, Nr. 67-2627.

[7] Naftos produktais užterštų teritorijų tvarkymo aplinkos apsaugos reikalavimai [Oil-contaminated site management of environmental requirements]. LAND 9-2009. - 2009-11-17. - Lietuvos Respublikos aplinkos ministro: isakymas Nr. D1-694. Vilnius: Aplinkos ministerija [Minister of Environment of the Republic of Lithuania: Order No. D1-694th Vilnius: Ministry of Environment], 2009. 20 p. Valstybes žinios. 2009 , Nr. 140-6174.

[8] Directive 2004/42/CE of the European Parliament and of the Council of 21 April 2004 on the limitation of emissions of volatile organic compounds due to the use of organic solvents in certain paints and varnishes and vehicle refinishing products and amending Directive 1999/13/EC.

[9] Халецкий, В.А. Модификация стиролакриловых пленкообразователей силиконовыми олигомерами [Modification of styrene acrylic film forming silicone oligomers] / В.А. Халецкий, З.К. Зинович // Лакокрасочные материалы и их применение [Coating materials and their application]. 2002. №9. С. 26-27.

[10] Халецкий, В.А. Исследование влияния модификации акриловых пленкообразователей на свойства лакокрасочных материалов [Investigation of influence of modification of acrylic film-forming properties of paints] / В.А. Халецкий, В.Н. Панагушин // Вестник Брестского государственного технического университета -Водохозяйственное строительство, теплоэнергетика, экология [Bulletin of the Brest State Technical Universitywater engineering, power system, and ecology]. 2003. №2. C. 81-83. 